\title{
Prey perception mechanism determines maximum clearance rates of planktonic
} copepods

Behavior-dependent clearance rates in planktonic copepods

\section{Almeda, Rodrigo; van Someren Gréve, Hans; Kiørboe, Thomas}

\section{Published in:}

Limnology and Oceanography

Link to article, DOI:

10.1002/Ino.10969

Publication date:

2018

Document Version

Peer reviewed version

Link back to DTU Orbit

Citation (APA):

Almeda, R., van Someren Gréve, H., \& Kiørboe, T. (2018). Prey perception mechanism determines maximum clearance rates of planktonic copepods: Behavior-dependent clearance rates in planktonic copepods. Limnology and Oceanography, 63(6), 2695-2707. https://doi.org/10.1002//no.10969

\section{General rights}

Copyright and moral rights for the publications made accessible in the public portal are retained by the authors and/or other copyright owners and it is a condition of accessing publications that users recognise and abide by the legal requirements associated with these rights.

- Users may download and print one copy of any publication from the public portal for the purpose of private study or research.

- You may not further distribute the material or use it for any profit-making activity or commercial gain

- You may freely distribute the URL identifying the publication in the public portal 
1 Revised manuscript LO-18-0052_post print

2

3 Prey perception mechanism determines maximum clearance rates of planktonic copepods

4

5

6 Rodrigo Almeda*, Hans van Someren Gréve \& Thomas Kiørboe

7

9

10 11

12

13

14

15

16

17

18

19

20

21

22

23

24 


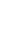
3 4

\section{Abstract}

The ecological consequences of "sit-and-wait” (ambushing) vs "searching” (active feeding) foraging strategies are not well understood in marine plankton food webs. We determined the maximum clearance rates of ambush and active feeders to evaluate the trade-off between foraging gain and predation risk associated with the main foraging strategies in planktonic copepods. We show that maximum clearance rates are similar among feeding behaviours for motile prey but one order of magnitude lower for ambush than for active feeders towards non-motile prey. The prey size spectrum is narrower and towards relatively larger prey in ambushers compared to active feeders. Prey detection in ambushers relies on the hydrodynamic disturbances and is inefficient towards non-motile prey but highly efficient for large motile prey. The effective prey perception mechanism in ambushers compensates for the lower prey encounter velocity in ambush feeding copepods compared to active feeding copepods. Therefore, ambushers are more restricted in target prey than active feeders and prey perception mechanism determines the efficiency of planktonic copepod foraging strategies. The lower clearance rates of ambush feeders on non-motile prey is compensated for by a lower predation risk, which can partially explain the coexistence of both "high-gain \& high-risk” (active feeders) and “low-gain \& low-risk” (ambush feeders) foraging strategies in marine plankton food webs. 45 “ 


\section{Introduction}

Zooplankton grazing is a pivotal biological process in the transfer of matter from lower to higher trophic levels in the sea (Banse 1995). Knowledge of zooplankton predator-prey interactions is therefore essential to understand the structure and dynamics of marine food webs. Traditionally, models of pelagic food webs quantify interactions between taxonomic groups or functional types, but attempts to embrace the inherent complexity of marine food webs make these models very complex (Anderson 2005; Flynn 2005). An alternative approach in marine plankton ecology, the trait-based approach, proposes to replace the many species with individuals that are characterized by a few key traits that are interrelated through trade-offs (i.e., costs and benefits of a particular trait) (Kiørboe 2011; Litchman et al. 2013). The key traits are those few properties that capture most of the Darwinian fitness of an organism. Identifying the key traits and quantifying their associated trade-offs in zooplankton will increase our ability to understand and predict the structure and function of plankton food webs (Litchman et al. 2013; Benedetti et al. 2015; Hébert et al. 2016). Foraging strategy is central to the success of copepods and must thus be considered a key trait (Kiørboe 2011; Litchman et al. 2013).

Suspension-feeding zooplankton have three main ways of obtaining food: they can be (1) "ambush feeders" that wait motionless for motile prey to pass within their sensory reach or capture those prey that directly collide (Jiang and Paffenhöfer 2008; Kiørboe 2011, 2016), (2) “feedingcurrent feeders" that hover while generating a feeding current and harvest prey that are entrained in the current (Strickler 1982, 1985; Kiørboe 2011), or (3) “cruising feeders” that cruise through the water and capture encountered prey (Tiselius and Jonsson 1990; Kiørboe 2011). These feeding behaviours can be broadly classified into two main foraging strategies: "sit-and-wait" (ambushing) vs. "searching” (active feeding). Some copepod species can switch between feeding behaviours (“mixed feeding behaviour”) depending on prey type or/and food availability (Landry 1981; 
Tiselius and Jonsson 1990; Kiørboe et al. 1996). This classification of feeding behaviours and foraging strategies applies across taxonomic groups, from small flagellates to large gelatinous zooplankton, and the different foraging modes are expected to have different benefits in terms of ability of obtaining food (foraging gain) and different costs in terms of mortality (predation risk) and metabolic expenses (Kiørboe et al. 2010, Abrams 2003). We have previously quantified the different costs associated with the main foraging behaviours in zooplankton through theoretical models and experimental testing, particularly mortality costs due to predation (Kiørboe et al. 2010; Kiørboe et al. 2014; Almeda et al. 2017; van Someren Gréve et al. 2017a). Here we aim at quantifying the benefits of the same foraging behaviours, specifically to quantify maximum clearance rates, to achieve a fuller understanding of the trade-offs of zooplankton small-scale foraging behaviours.

Zooplankton feeding has been extensively studied in both the laboratory and the field and experimental studies have focused mainly on the effect of grazer and prey size and food concentration (Harris and Paffenhöfer 1976; Ikeda 1977; Hansen et al. 1997; Saiz and Calbet 2007; Almeda et al. 2010a; Gonçalves et al. 2014; Helenius and Saiz 2017), while none have compared thoroughly the clearance efficiency of the different feeding behaviours/foraging strategies . Differences in methods and environmental conditions among previous studies complicate direct comparisons of maximum clearance rates in zooplankton feeding behaviours. Theoretical analyses by Kiørboe (2011) suggest that feeding-current feeding (hovering) is the most efficient behaviour and ambush feeding the least efficient in terms of volume of water cleared. Specifically, ambush feeding is expected to be $\sim 3-10$ times less efficient than the active foraging behaviours, mainly because the predator-prey encounter is higher when due to the predator velocity than to a smaller prey velocity (Kiørboe 2011). In addition, ambush-feeding copepods depend on the fluid disturbance generated by motile prey to perceive the prey (Kiørboe et al. 1999; Kiørboe and Visser 
1999) and are therefore expected to be inefficient on non-motile prey and prey that does not create a sufficiently strong hydromechanical signal (Jiang and Paffenhöfer 2008; Kiørboe 2011; Henriksen et al. 2007; Saiz et al. 2014).

Here, we experimentally test the hypotheses that (i) ambush feeders are less efficient than the active feeders (feeding-current and cruising feeders) in acquiring resources, and (ii) that ambushers are particularly poor in collecting non-motile prey (Fig.1). We quantify the functional feeding responses, i.e., the changes in feeding rates as a function of food concentration (Holling 1959), of copepod nauplii and copepodites displaying the three main feeding strategies, to estimate maximum clearance rates of each strategy. We use prey of different size and motility to estimate the influence of these aspects on maximum clearance rates. Our results are relevant to quantify the gain over risk of the main zooplankton feeding strategies (Kiørboe 2011) and help to understand the spatiotemporal distribution and coexistence of the different zooplankton foraging strategies in marine environments (Barton et al. 2013; Brun et al. 2016).

\section{Methods}

Experimental organisms.

Nauplii and copepodites of Oithona nana (ambush feeders, Kiørboe 2011), Temora longicornis (feeding-current feeder, Kiørboe 2011), and Centropages hamatus (cruising feeder, Kiørboe 2011; Tiselius and Jonsson 1990) were used as model organisms for the three main feeding strategies in zooplankton (Table 1). O. nana is a strict ambush feeder during all its development. All $T$. longicornis life stages are feeding-current feeders. C. hamatus nauplii are strict cruising feeders without generating a feeding-current while the copepodites are considered cruising feeders that can also generate a feeding-current. The three experimental species were also selected because they are common and abundant in coastal waters (Razouls et al. 2005; Temperoni et al. 2010; Martynova et 

al. 2011), play important ecological roles in food webs (Lampitt 1978; Casini et al. 2004), and can be reared in the laboratory. Description of the motile behaviours of the experimental stages can be found in van Gréve Someren et al. (2017a). We used four different prey in the experiments: the cryptophyte flagellate Rhodomonas salina, the diatom Thalassiosira weissflogii, the heterotrophic dinoflagellate Oxyrrhis marina and the mixotrophic dinoflagellate Akashiwo sanguinea (Table 1). R. salina, T. weissflogii and A. sanguinea cultures were kept in exponential growth in B1 culture medium (Hansen 1989) and maintained at $18^{\circ} \mathrm{C}$ and on a 12:12-h light/dark cycle in glass flasks. $O$. marina was fed on the $R$. salina and maintained at $18^{\circ} \mathrm{C}$ in $2-\mathrm{L}$ glass bottles in dark.

The copepods were grown in continuous laboratory cultures in 30- and 100-L plastic tanks at 15$18^{\circ} \mathrm{C}$ in dark. Specimens of O. nana, T. longicornis and C. hamatus were originally isolated from the Port of Gijon (Cantabrian Sea, Spain), the Øresund strait (North Sea, Denmark) and the Skagerrak (North Sea, Sweden), respectively. O. nana cultures were fed on the heterotrophic dinoflagellate O. marina ad libitum. T. longicornis and C. hamatus cultures were fed with mixed cultured phytoplankton (R. salina, T. weissflogii, Heterocapsa triquetra, Prorocentrum minimum, A. sanguinea in a proportion of 1, 0.4, 0.2, 0.1 and 0.1 , respectively), and in the case of $C$. hamatus, also with O. marina.

To obtain cohorts of O. nana, T. longicornis, and C. hamatus, we separated adults from the stock culture with 125 - or 200- $\mu \mathrm{m}$-mesh sieves and placed them separately in a new tank. After $48 \mathrm{~h}$, adults were removed with a 100- or 200- $\mu$ m-mesh sieve, and eggs/hatched nauplii were transferred to a new tank with food ad libitum. We let nauplii grow until the desired stage/length was reached (Table 1).

\section{Functional feeding response experiments}

We determined feeding rates of nauplii and copepodites with different feeding behaviour using four different prey offered separately (Table 1). Functional response curves were obtained by 
quantifying feeding rates at five different prey concentrations using bottle incubations (Frost 1972). Before starting the experiments, $T$. weissflogii stock culture was filtered through $12-\mu \mathrm{m}$ mesh to remove any cell aggregates. O. marina was not fed four days prior to the experiment to avoid the presence of $R$. salina in the experiment. We verified the absence of $R$. salina in the O. marina culture using a coulter counter and an inverted microscope before starting experiments.

For each experiment, total body length of nauplii and prosome length in copepodites were measured in 30 individuals (Table 1). Length measurements were converted to carbon weight using the equations of Klein Breteler et al. (1982) for T. longicornis and C. hamatus and of Almeda et al. (2010b) for O. nana (Table 1). Prey size (equivalent spherical diameter, ESD, $\mu \mathrm{m}$ ) and prey concentrations (cells $\mathrm{mL}^{-1}$ ) of the stock cultures were determined at the start of each experiment using a Beckman Multisizer III Coulter Counter. Cell volumes were converted to carbon content according to Pelegri et al. (1999) for O. marina, Henriksen et al. (2007) for T. weissflogii, MendenDeuer and Lessard (2000) for A. sanguinea and Montagnes et al. (1994) for $R$. salina.

Prey suspensions were prepared by successive dilution of the highest food concentration with 0.2 $\mu \mathrm{m}$ filtered seawater and amended with growth medium $\left(1 \mathrm{~mL} \mathrm{~L}{ }^{-1}\right)$ to avoid differential phytoplankton growth between treatments due to nutrient excretion by copepods. For each prey concentration, bottles (35-68 mL) were filled with the corresponding prey suspension. For each concentration, 3 bottles were used to determine the initial prey concentration ( "initials"), 3 bottles were used to determine prey growth rates during the incubation without copepods ( "control bottles”) and 3 bottles with copepods served as experimental treatments (“experimental bottles”). Nauplii and copepodites were either picked individually under a stereomicroscope or, in most of the cases, concentrated using a $40 \mu \mathrm{m}$ mesh-sieve, counted and added as aliquots to the experimental bottles. The number of nauplii and copepodites added to the experimental bottles varied depending on copepod species, prey type and prey concentration (Table 1) and the grazer concentrations were 
chosen to ensure a reduction of $\sim 30 \%$ in prey concentration during incubation according to previous studies (e.g., Almeda et al. 2010a; Saiz et al. 2014; Helenius and Saiz 2017). The experimental and control bottles were mounted on a rotating wheel $(0.4 \mathrm{rpm})$ and incubated at $15^{\circ}$ $\mathrm{C}$ for $\sim 24 \mathrm{~h}$ in dark.

After incubation, the bottle contents were filtered through a $40-\mu \mathrm{m}$ mesh and nauplii and copepodites were checked for mortality and fixed with 1\% Lugol's solution. The mortality of nauplii and copepods was negligible and initial nominal grazer concentrations were considered for the calculations. Samples from initials, experimental, and control bottles were fixed with $1 \%$ Lugol's solution. Prey concentration in each sample was determined under an inverted microscopy using Sedgewick-Rafter counting chambers $(1 \mathrm{~mL})$ or Uhtermol settling chambers $(5-100 \mathrm{~mL})$ depending on cell densities to ensure that the entire samples (for low prey concentration) or at least 200 cells were counted.

\section{Calculations}

Clearance rates, ingestion rates, and average prey concentration during the incubations were calculated according to Frost (1972). The functional feeding response of planktonic copepods commonly follows a type II or III model (Holling, 1959, Kiørboe et al. 2018). The type III functional response differs from type II in the presence of a 'feeding threshold', i.e., a prey concentration below which the copepod reduces its clearance rates (Kiørboe et al., 1985, 2018). The measured clearance rates $\left(F, \mathrm{~mL}\right.$ ind..$\left.^{-1} \mathrm{~d}^{-1}\right)$ and ingestion rates $\left(I\right.$, cells ind.$\left.^{-1} \mathrm{~d}^{-1}\right)$ in relation to prey concentration $\left(C\right.$, cells $\left.\mathrm{mL}^{-1}\right)$ were fitted to either a Holling functional response type II or type III model (Kiørboe, 2008a; Schultz and Kiørboe 2009):

$$
\text { Holling type II: }
$$

$$
F=\beta(1+\beta \tau C)^{-1}
$$$$
I=\beta C(1+\tau \beta C)^{-1}
$$

Holling type III:

$$
F=(\alpha \beta / C) \mathrm{e}^{1-\alpha / C}
$$


where $\beta$ is the maximum clearance rate (mL ind. ${ }^{-1} \mathrm{~d}^{-1}$ ), $\tau$ is the prey handling time (d) and $\alpha$ is the prey concentration at the maximum clearance rate. Maximum ingestion rates ( $\mathrm{I}_{\max }$, cells ind. ${ }^{-1} \mathrm{~d}^{-1}$ ) were calculated as $\tau^{-1}$ (eq. 2) or $\alpha \beta e^{1}$ (eq. 4). A type III model was fitted to the data when a decrease in clearance rates was observed at the lowest prey concentration, which implies the presence of a "feeding threshold concentration", ( $\alpha$ in equation 3 and 4). When a feeding threshold concentration was absent or unclear, the type of model was chosen based on the best statistical fit by visually inspecting the fitted models on plotted data and by comparing the correlation coefficient $\left(\mathrm{R}^{2}\right)$ and standard error (SE) of the estimates from both fits.

Carbon-specific maximum clearance rates $\left(\beta_{s}, \mathrm{~mL} \mu \mathrm{gC}^{-1} \mathrm{~d}^{-1}\right)$ as a function of the prey: predator size ratio $(x)$ were fitted to a Gaussian function:

$\beta_{\mathrm{s}}=\gamma e^{-0.5\left[(x-\mu) / \sigma^{2}\right]}$

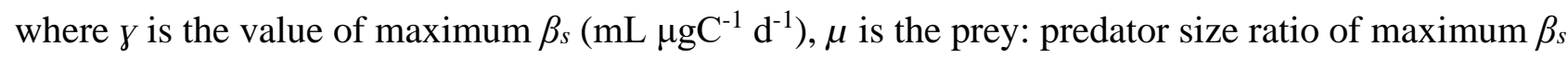
and $\sigma$ is the standard deviation.

To compare maximum clearance rates $(\beta)$ among feeding behaviours depending on body weight $(W)$, we used analysis of covariance (ANCOVA) to test for significant differences in slopes $(b)$ and intercepts (a) among linear regressions fitted to the logarithmically transformed data i.e., $\log (\beta)=\mathrm{a}$ + b log (W). Post hoc Bonferroni test was used for pairwise comparison. All statistical tests were conducted with IBM-SPSS software and a statistical significance level of 0.05 was applied.

\section{Results}

Clearance rates of nauplii and copepodites of O. nana (ambush feeders, Fig. 2), T. longicornis (feeding-current feeders, Fig. 3), and C. hamatus (cruising feeder, Fig. 4) varied depending on food concentration following mostly a type III and, in some cases, a type II functional feeding response 
215 (Figs. 2-4). Cruising feeders and feeding-current feeders showed type III functional response for all 216 the prey (Fig. 3 and 4, Table 2) except for T. longicornis feeding on O. marina (Fig. 3 H-J, Table 217 2). In ambush feeders, we found both type II and III functional responses depending on the prey 218 type and copepod stage (Fig. 2, Table 2). Except for nauplii feeding on O. marina (Fig. 2 I-K), the 219 decrease in clearance rates at the lowest concentration in ambush feeders was, however, relatively low, and even though a functional response type III model was fitted to the data (Table 2), a type II model fitted the data almost equally well. Ingestion rates increased with increasing prey concentration until, in most cases, reaching saturation (Fig. 2-4). Saturation of ingestion rates was, however, not clearly observed in some experiments (Fig. 2 E-H; Fig. 3 H-J, Fig. 4 H-K) and, in these cases, the estimated maximum ingestion rates (Table 2) should be considered with caution. The lack of saturation was particularly evident in ambush feeders feeding on diatoms (Fig.2, E-H). Functional response parameters and carbonspecific maximum ingestion rates for the different feeding behaviours and prey type are shown in Table 2.

Maximum clearance rates $\left(\mathrm{mL}_{\mathrm{ind}} \mathrm{d}^{-1} \mathrm{~d}^{-1}\right)$ increased with increasing grazer body weight for each of the four prey (Fig. 5). We did not find significant differences in maximum clearances rates $(\beta)$ among feeding behaviours when prey was motile (ANCOVA, p>0.05) (Fig. 5 B-C). However, maximum clearances rates $(\beta)$ of ambush feeders were about one order of magnitude lower than for feeding-current and cruising feeders when non-motile diatoms were offered as food (ANCOVA, (Fig. 5E) was higher and the prey size spectrum narrower than in feeding-current and cruising feeders (Fig. 5F-G). $\mathrm{p}<0.05)$ (Fig. 5A). Carbon-specific maximum clearance rates $\left(\beta_{s}, \mathrm{~mL} \mu \mathrm{g} \mathrm{C} \mathrm{C}^{-1} \mathrm{~d}^{-1}\right)$ varied with the prey to predator size ratio (Fig. 5 E-G) and the optimal prey to predator size ratio in ambush feeders 


\section{Discussion}

Since the first video observations of planktonic copepods in the 80s (Alcaraz et al. 1980; Koehl and Strickler 1981; Paffenhöfer et al. 1982), several studies have emphasized the importance of investigating small-scale individual behaviours to attain a better mechanistic understanding of planktonic organisms’ interactions and marine food webs dynamics (Henriksen et al. 2007; Kiørboe, 2008, 2011; Kiørboe et al. 2014). Our previous research and others studies on behavioural observations and feeding mechanisms of planktonic copepods (e.g., Price et al. 1983; Kiørboe et al. 2009; Kiørboe 2011; Bruno et al. 2012; Cheng et al. 2014; van Someren Gréve et al. 2017a;

Gonçalves et al. 2014) allow us to interpret the results obtained here from bottle incubations.

\section{Feeding efficiency of different zooplankton foraging strategies}

We found that, in contrast to model predictions (Kiørboe 2011), maximum clearance rate in the three studied behaviours was similar for motile prey with a size range of 7-40 $\mu \mathrm{m}$ and therefore our first hypothesis was rejected. Our hypothesis was based on the fact that prey encounter velocities are higher in active than in ambush feeders, and that clearance rate scales with prey encounter velocity (Kiørboe 2011). However, clearance rates also vary with prey detection distance squared, and therefore even a relatively small increase in prey detection distances in ambushers compared to active feeders may compensate for the lower encounter velocities. Prey are perceived, captured and handled individually by all three feeding behaviours (Price et al. 1983; Kiørboe 2011; Bruno et al. 2012) but ambush feeders perceive their prey differently than active feeders. Ambush feeding copepods respond to the fluid disturbance generated by motile prey and thus may perceive their prey at a considerable distance (Svensen and Kiørboe 2000; Kiørboe et al. 2009; Cheng et al. 2014) while active feeders appear rather to perceive their prey as they are touched, or nearly touched, by the setae on the feeding appendages (Uttieri et al. 2008; Tiselius et al. 2013; Gonçalves and Kiørboe 2015). 
Our second hypothesis was confirmed since ambush feeding was clearly an inefficient foraging strategy for non-motile prey like diatoms. This is in agreement with previous experimental field and laboratory studies and model predictions (Atkinson 1995; Kiørboe and Visser 1999; Paffenhöfer and Mazzocchi 2002; Vogt et al. 2013; Henriksen et al. 2007; Saiz et al. 2014; van Someren Gréve et al. 2017b). Prey motility can affect encounter rates by increasing the relative speed between predator and prey and by increasing prey detectability by a rheotactic predator. In active feeding behaviours (feeding-current and cruise feeders), the contribution of prey motility to predator-prey encounter rate is negligible due to the difference in swimming velocity between a large predator and a small prey (Kiørboe 2011). In ambush feeders, which wait motionless in the water column, prey velocity can affect encounter rates and detectability (Kiørboe 2011). Thus, the strict ambush feeders Oithona have a very low clearance efficiency on non-motile prey (diatoms) and a high clearance efficiency on the fast swimming prey Oxyrrhis marina (307-700 $\mu \mathrm{m} \mathrm{s}^{-1}$, Cosson et al. 1988). Rapidly sinking non-motile prey, e.g., faecal pellets, may still be perceived by ambush feeders, and sinking particles may directly intercept/collide with the copepod feeding structures (Turner 1986; Hopkins and Torres 1989; González and Smetacek 1994; Atkinson 1995; Kiørboe and Visser 1999). This mechanism may account for the non-zero feeding on diatoms by ambush feeders in our experiments. The observed low feeding rates and lack of a saturation response in O. nana when fed on diatoms suggests that feeding rates remain encounter-limited rather than digestion-limited simply because few diatom cells are encountered by chance, even at the highest prey concentrations examined. The differences in prey perception mechanism between active and ambush foraging also leads to the prediction that ambush feeders have a narrower prey size spectrum and a larger optimum prey: predator size ratio than active feeders, as observed in Kiørboe 2016. Trade-off between foraging gain and predation risk and its ecological implications. 
Our results on behaviour-dependent clearance rates help to understand the trade-offs of different feeding behaviours (foraging gain vs predation risk) and to predict optimal feeding strategies in marine food webs depending on the environmental conditions (e.g. type of food resources: motile vs non-motile prey, low or high predation pressure). Ambush feeding is an inefficient behaviour for non-motile prey as diatoms, that is the dominant prey during spring blooms in temperature latitudes. Then, active feeders, which are highly efficient feeding on diatoms, would have an advantage over ambush feeders during spring blooms. In fact, calanoid copepods with active feeding behaviours are commonly dominant during diatom spring blooms (Kenitz et al. 2017). However, the presence of motile prey (e.g., ciliates and dinoflagellates) during diatoms blooms may also allow the occurrence of ambush feeding copepods (e.g., Oithona similis) in spring phytoplankton blooms (e.g., Atkinson, A. 1995; Castellani et al. 2007). Ambush feeding is a highly successful strategy and ambushfeeding copepods (Oithona spp) are considered among the most abundant copepods in the oceans (Gallienne and Robins 2001) even though they are less efficient than the other feeding behaviours for non-motile prey. This is likely due to the stealth of ambush feeding compared to active feeding behaviours and the consequently lower predation risk. Estimates of predation risks of active versus passive feeding strategies based on the motile behaviour (van Someren Gréve et al. 2017a) and fluid signals that feeding generates (Kiørboe et al. 2010) suggest that ambush feeders have up to an order of magnitude lower predation risk compared to active feeders. This estimate has been verified experimentally (Almeda et al. 2017) and is consistent with (rare) field estimates of mortality rates in copepods (Eiane and Ohman 2004). In addition, ambushers are expected to have a metabolic cost lower than actively feeding copepods (Castellani et al. 2005, Kiørboe 2010; Almeda et al. 2011). A lower energetic demand can allow a higher starvation tolerance. Thus, ambush feeding is expected to be less costly than active feeding also in terms of energy expenditure. This may explain why Oithona spp. (copepod species without resting eggs and low lipid content) can cope with food 
limitation along the year in seasonal systems and be a dominant copepod in both oligotrophic and eutrophic environments. An optimal foraging strategy is not necessarily the one that leads to the highest feeding rate, but the one that optimizes the net gain over the risk/loss.

The trade-off between foraging gain and predation risk in planktonic copepods has at least two implications: First, it promotes species diversity since two different strategies can be equally fit in many environments. It allows coexistence of species that feed on very much the same resources and where the more efficient feeder (competition specialist) would otherwise out-compete the less efficient (defence specialist) according to the competitive exclusion principle (Gause 1934; Hardin 1960). Generally, diversity is generated by co-existing species that distribute themselves along a gradient from competition to defence specialists (Thingstad et al. 2005; Winter et al. 2010). This idea is rather well developed for prokaryotes competing for dissolved organics and defending themselves against virus attacks and grazing (Våge et al. 2013), but much less explored for other organisms such as copepods. We argue that the trade-off between feeding and survival is an important source of diversity in zooplankton communities. Second, some environments may favour one strategy over another, and whichever is the most 'fit' foraging strategy in any particular environment depends on the presence and density of predators and on the availability and type of prey. This would imply a distinct feeding trait biogeography if such environments were recurrent (Visser 2007, Barton et al 2013, Brun et al. 2016).

Overall, feeding behaviour, prey perception mechanisms, and prey motility are main determinants of predator-prey interactions in plankton food webs accounting for order of magnitude differences in feeding rates and predation mortalities in planktonic copepods. These important differences are not captured by models of pelagic systems operating with ‘functional types’ (e.g., Baretta et al. 1997), but are increasingly being built into trait-based models and may help to predict essential features of the seasonal succession of plankton communities (Mariani et al. 2013). 
Data accessibility: The data from this work are archived at the Dryad repository:

http://datadryad.org/review?doi=doi:10.5061/dryad.q0f5f

Competing interests: We have no competing interests.

Authors' contributions: RA, TK and HVSG conceived and designed the experiments. RA and HVSG performed the experiments, RA analysed the data and all authors contribute to the data interpretation. RA wrote the paper with substantial input from TK and HSVG. All authors gave final approval for publication.

Acknowledgments: We thank Rocío Rodríguez-Torres, Karolina Molla-Gazi, Ryan HackettBrooks, Miguel Martin Herreros and Juan Carlos Torres for their help with sample analysis. We also thank Jack Melbye for maintaining the continuous phytoplankton and copepod cultures.

Funding: This research was made possible by a DFF-Individual postdoctoral grant (17023) from the Danish Council for Independent Research to R.A., a Marie Curie Intra-European fellowship from the People Programme of the European Union's Seventh Framework Programme FP7/20072013/ under REA grant agreement number 6240979 to R.A. and a Hans Christian Ørsted Postdoctoral fellowship from Technical University of Denmark to R.A.. The Centre for Ocean Life is a VKR Center of Excellence funded by the Villum Foundation. 


\section{References}

Abrams, P.A. (2003) Can adaptive evolution or behaviour lead to diversification of traits determining a trade-off between foraging gain and predation risk? Evol. Ecol. Res. 5, 653-670.

Alcaraz, M., Paffenhöfer, G. A., Strickler, J. 1980. Catching the algae a first account of visual observations on filter-feeding copepods, p. 241-248. In W.C. Kerfoot [ed.], Evolution and Ecology of Zooplankton Communities. The University Press of New England.

Almeda, R., Augustin, C. B., Alcaraz, M., Calbet, A., Saiz, E. 2010a. Feeding rates and gross growth efficiencies of larval developmental stages of Oithona davisae (Copepoda, Cyclopoida). J. Exp. Mar. Biol. Ecol. 387: 24-35.

Almeda, R., Calbet, A., Alcaraz, M., Yebra, L., Saiz, E. 2010b. Effect of temperature and food concentration on survival, development and growth rates of naupliar stages of Oithona davisae (Copepoda, Cyclopoida). Mar. Ecol. Prog. Ser. 410: 97-109. Almeda R., Alcaraz M., Calbet A., Saiz E. 2011. Metabolic rates and carbon budget of early developmental stages of the marine cyclopoid copepod Oithona davisae. Limnol. Oceanogr. 56: 403-414.

Almeda, R., van Someren Gréve, H., Kiørboe, T. 2017. Behavior is a major determinant of predation risk in zooplankton. Ecosphere 8: e01668.

Anderson, T. R. 2005. Plankton functional type modelling: running before we can walk. J. Plankton Res. 27: 1073-1081.

Atkinson, A. 1995. Omnivory and feeding selectivity in five copepod species during spring in the Bellingshausen Sea, Antarctica. ICES J. Mar. Sci. 52: 385-396.

Barton, A.D., Pershing, A.J., Litchman, E., Record, N.R., Edwards, K.F., Finkel, Z.V. Kiørboe, T., Ward, B.A. 2013. The biogeography of marine plankton traits. Ecol. Lett. 16: 522-534 
Banse, K. 1995. Zooplankton: pivotal role in the control of ocean production. ICES J. Mar. Sci. 52: 265-277.

Baretta, J. W., Ebanhoh, W., Ruardij, P. 1997. The European Regional Seas Ecosystem Model (ERSEM) II. J. Sea Res. 38: 229-483.

Benedetti, F., Gasparini, S., Ayata, S. D. 2015. Identifying copepod functional groups from species functional traits. J. Plankton Res. 38: 159-166.

Brun, P., Payne, M. R., Kiørboe, T. 2016. Trait biogeography of marine copepods - an analysis across scales. Ecol. Lett. 19: 1403-1413.

Bruno, E., Andersen Borg, C. M., Kiørboe, T. 2012. Prey detection and prey capture in copepod nauplii. PLoS One 7: e47906.

Casini, M., Cardinale, M., Arrhenius, F. 2004. Feeding preferences of herring (Clupea harengus) and sprat (Sprattus sprattus) in the southern Baltic Sea. ICES Journal of Marine Science 61: 12671277.

Castellani, C., Irigoien, X., Harris, R.P., Holliday, N.P. 2007. Regional and temporal variation of Oithona spp. biomass, stage structure and productivity in the Irminger Sea, North Atlantic. J. Plankton Res., 29: 1051-1070. Cheng, W., Akiba, T., Omura, T., Tanaka, Y. 2014. On the foraging and feeding ability of Oithona davisae (Crustacea, Copepoda). Hydrobiologia 741: 167-176.

Cosson, J., Cachon, M., Cachon, J., Cosson, M.-P. 1988. Swimming behaviour of the unicellular biflagellate Oxyrrhis marina: in vivo and in vitro movement of the two flagella. Biol. Cell 63: 117126. 
401 Eiane, K., Ohman, M. D. 2004. Stage specific mortality of Calanus finmarchicus, Pseudocalanus 402 elongatus and Oithona similis on Fladen Ground, North Sea, during a spring bloom. Mar. Ecol. 403 Prog. Ser. 268: 183-193.

404 Flynn, K. J. 2005. Castles built on sand: dysfunctionality in plankton models and the inadequacy of 405 dialogue between biologists and modellers. J. Exp. Mar. Biol. Ecol. 27: 1205-1210.

406 Frost, B. W. 1972. Effects of size and concentration of food particles on the feeding behavior of the 407 marine planktonic copepod Calanus pacificus. Limnol. Oceanogr. 17: 805-815.

408 Gallienne, C. P., Robins, D. B. 2001. Is Oithona the most important copepod in the world's oceans? 409 J. Plankton Res. 23: 1421-1432.

410 Gause, G. 1934. The struggle for existence. Williams and Wilkins; Baltimore.

411 Gonçalves, R., van Someren Gréve, H., Couespel, D., Kiørboe, T. 2014. Mechanisms of prey size 412 selection in a suspension-feeding copepod, Temora longicornis. Mar. Ecol. Prog. Ser. 517: 61-74.

413 Gonçalves, R. J., Kiørboe, T. 2015. Perceiving the algae: how feeding-current feeding copepods 414 detect their non-motile prey. Limnol. Oceanogr. 60: 1286-1297.

415 González, H. E., Smetacek, V. 1994. The possible role of the cyclopoid copepod Oithona in 416 retarding vertical flux of zooplankton faecal material. Mar. Ecol. Prog. Ser. 113: 233-246.

417 Hansen, P. J. 1989. The red tide dinoflagellate Alexandrium tamarense : effects on behaviour and 418 growth of a tintinnid ciliate. Mar. Ecol. Prog. Ser. 53: 105-116.

419 Hansen, P. J., Bjørnsen, P. K., Hansen, B. W. 1997. Zooplankton grazing and growth: Scaling 420 within the 2-2,000- $\mu$ m body size range. Limnol. Oceanogr. 42: 687-704.

421 Hardin, G. 1960. The competition exclusion principle. Science 131: 1292-1297. 
Harris, R. P., Paffenhöfer, G.-A. 1976. The effect of food concentration on cumulative ingestion

423

424

425

426

427

428

429

430

431

432

433

434

435

436

437

438

439

440

441

442 and growth efficiency of two small marine planktonic copepods. J. Mar. Biol. Ass. U.K. 56: 875888.

Hébert, M.-P., Beisner, B. E., Maranger, R. 2016. A meta-analysis of zooplankton functional traits influencing ecosystem function. Ecology 97: 1069-1080.

Helenius, L. K., Saiz, E. 2017. Feeding behaviour of the nauplii of the marine calanoid copepod Paracartia grani Sars: Functional response, prey size spectrum, and effects of the presence of alternative prey. PLoS ONE 12: e0172902.

Henriksen, C., Saiz, E., Calbet, A., Hansen, B. 2007. Feeding activity and swimming patterns of Acartia grani and Oithona davisae nauplii in the presence of motile and non-motile prey. Mar. Ecol. Prog. Ser. 331: 119-129

Holling, C. S. 1959. Some characteristics of simple types of predation and parasitism. Can. Entomol. 91: 824-839.

Hopkins, T. L., Torres, J. J. 1989. Midwater food web in the vicinity of a marginal ice zone in the western Weddell Sea. Deep-Sea Res. A 36: 542-560.

Ikeda, T. 1977. Feeding rates of planktonic copepods zooplankton from a tropical sea. J. Exp. Mar. Biol. Ecol. 29: 263-277.

Jiang, H. S., Paffenhöfer, G.-A. 2008. Hydrodynamic signal perception by the copepod Oithona plumifera. Mar. Ecol. Prog. Ser. 373: 37-52.

Kenitz, K. M., Visser, A. W., Mariani, P., Andersen, K. H. 2017. Seasonal succession in zooplankton feeding traits reveals trophic trait coupling. Limnol. Oceanogr. 62: 1184-1197 
443 Kiørboe, T., Saiz, E., Viitasalo, M. 1996. Prey switching behaviour in the planktonic copepod 444 Acartia tonsa. Mar. Ecol. Prog. Ser. 143: 65-75.

445 Kiørboe, T., Saiz, E., Visser, A. W. 1999. Hydrodynamic signal perception in the copepod Acartia 446 tonsa. Mar. Ecol. Prog. Ser. 179: 97-111.

447 Kiørboe, T., Visser, A. W. 1999. Predator and prey perception in copepods due to hydromechanical 448 signals. Mar. Ecol. Prog. Ser. 179: 81-95.

449 Kiørboe, T. 2008. A mechanistic approach to plankton ecology. Princeton: Princeton University 450 Press.

451 Kiørboe, T., Andersen, A., Langlois, V. J., Jakobsen, H. H., Bohr, T. 2009. Mechanisms and 452 feasibility of prey capture in ambush-feeding zooplankton. Proc. Natl Acad. Sci. USA 106: 1239445312399.

454 Kiørboe, T., Jiang, H., Colin, S. P. 2010. Danger of zooplankton feeding: The fluid signal generated 455 by ambush feeding copepods. Proc. Roy. Soc. B. 277: 3229-3237.

456 Kiørboe, T. 2011. How zooplankton feed: mechanisms, traits and trade-offs. Biol. Rev. Camb. 457 Philos. Soc. 86: 311-339.

458 Kiørboe, T., Jiang, H., Goncalves, R. J., Nielsen, L. T., Wadhwa, N. 2014 Flow disturbances 459 generated by feeding and swimming zooplankton. Proc. Natl. Acad. Sci. USA 111: 11738-11743. 460 Kiørboe, T., Ceballos, S., Thygesen, U. H. 2015. Interrelations between senescence, life history 461 traits, and behaviour in planktonic copepods. Ecology 96: 2225-2235.

462 Kiørboe, T. 2016. Foraging mode and prey size spectra of suspension-feeding copepods and other 463 zooplankton. Mar. Ecol. Prog. Ser. 558: 15-20. 
Klein Breteler, W. C. M., Fransz, H. G., Gonzalez, S. R. 1982. Growth and development of four calanoid copepod species under experimental and natural conditions. Netherlands J. Sea Res. 16: 195-207.

Koehl, M. A. R., Strickler, J. R. 1981. Copepod feeding currents: Food capture at low Reynolds number. Limnol. Oceanogr. 26: 1062-1073.

Lampitt R. S., Gamble J. C. 1982. Diet and respiration of the small planktonic marine copepod Oithona nana. Mar. Biol. 66:185-190

Landry, M. R. 1981. Switching between herbivory and carnivory by the planktonic marine copepod Calanus pacificus. Mar. Biol. 65: 77-82.

Litchman, E., Ohman, M. D., Kiorboe, T. 2013. Trait based approaches to zooplankton communities. J. Plankton Res. 35: 473-484.

Martynova, D. M., Kazus, N. A., Bathmann, U. V., Graeve, M., Sukhotin, A. A. 2011. Seasonal abundance and feeding patterns of copepods Temora longicornis, Centropages hamatus and Acartia spp. in the White Sea (66 N). Polar Biol. 34: 1175-1195.

Mariani, P., Andersen, K. H., Visser, K. H., Barton, A. D., Kiørboe, T. 2013. Control of plankton seasonal succession by adaptive grazing. Limnol. Oceanogr. 58: 173-184.

Menden-Deuer, S., Lessard, E. J. 2000. Carbon to volume relationships for dinoflagellates, diatoms, and other protist plankton. Limnol. Oceanogr. 45: 569-579.

Montagnes, D. J. S., Berges, J. A., Harrison, P. J., Taylor, F. J. R. 1994. Estimating carbon, nitrogen, protein, and chlorophyll a from volume in marine phytoplankton. Limnol. Oceanogr. 39: 1044-1060. 
485 Paffenhöfer, G.-A., Strickler, J. R., Alcaraz, M. 1982. Suspension feeding by herbivorous calanoid 486 copepods: A cinematographic study. Mar. Biol. 67: 193-199.

487 Paffenhöfer, G.-A., Mazzocchi, M. G. 2002. On some aspects of the behaviour of Oithona 488 plumifera (Copepoda: Cyclopoida). J. Plankton Res. 24: 129-135.

489 Pelegri, S. P., Dolan, J., Rassoulzadegan, F. 1999. Use of high temperature catalytic oxidation 490 (htco) to measure carbon content of microorganisms. Aquat. Microb. Ecol. 16: 273-280.

491 Price, H. J., Paffenhöfer, G.-A., Strickler, J. R. 1983. Modes of cell capture in calanoid copepods. 492 Limnol. Oceanogr. 28: 116-123.

493 Razouls C., de Bovée F., Kouwenberg J. et Desreumaux N., 2005-2018. - Diversity and Geographic 494 Distribution of Marine Planktonic Copepods. Sorbonne Université, CNRS. Available 495 at http://copepodes.obs-banyuls.fr/en [Accessed March 27, 2018]

Saiz, E., Calbet, A. 2007. Scaling of feeding in marine calanoid copepods. Limnol. Oceanogr. 52: $498 \quad 668-675$.

499 Saiz, E., Griffell, K., Calbet, A., Isari, S. 2014. Feeding rates and prey : predator size ratios of the 500 nauplii and adult females of the marine cyclopoid copepod Oithona davisae. Limnol. Oceanogr. 59: $501 \quad 2077-2088$.

502 Schultz, M. and Kiørboe, T. 2009. Active prey selection in two pelagic copepods feeding on 503 potentially toxic and non-toxic dinoflagellates. J. Plankton Res. 31, 553-561.

504 Strickler, J. R. 1982. Calanoid copepods, feeding currents, and the role of gravity. Science 218: 505 158-160. 
506

507

508

509

510

511

512

513

514

515

516

517

518

519

520

521

522

523

524

Strickler, J. R. 1985. Feeding currents in calanoid copepods: two new hypotheses. Symp. Soc. Exp. Biol. 39: 459-485.

Svensen, C., Kiørboe, T. 2000. Remote prey detection in Oithona similis: hydromechanical versus chemical cues. J. Plankton Res. 22: 1155-1166.

Temperoni, B., Viñas, M.D., Diovisalvi, N., Negri, R. 2011. Seasonal production of Oithona nana Giesbrecht, 1893 (Copepoda: Cyclopoida) in temperate coastal waters off Argentina. J. Plankton Res. 33:729-740.

Thingstad, T. F., Øvreås, L., Egge, J. K., Løvdal, T., Heldal, M. 2005. Use of non-limiting substrates to increase size; a generic strategy to simultaneously optimize uptake and minimize predation in pelagic osmotrophs? Ecol. Lett. 8: 675-682.

Tiselius, P., Jonsson, P. 1990. Foraging behaviour of six calanoid copepods: observations and hydrodynamic analysis. Mar. Ecol. Prog. Ser. 66: 23-33.

Tiselius, P., Saiz, E., Kiørboe, T. 2013. Sensory capabilities and food capture of two small copepods, Paracalanus parvus and Pseudocalanus sp. Limnol. Oceanogr. 58: 1657-1666.

Turner, J.T. 1986. Zooplankton feeding ecology: contents of fecal pellets of the cyclopoid copepods Oncaea venusta, Corycaeus amazonicus, Oithona plumifera, and O. simplex from the northeastern Gulf of Mexico. Mar. Ecol. 7: 289-302.

Uttieri, M., Paffenhöfer, G.-A., Mazzocchi, M. G. 2008. Prey capture in Clausocalanus furcatus (Copepoda: Calanoida). The role of swimming behaviour. Mar. Biol. 153: 925-935. 
525 Våge, S., Storesund, J. E., Thingstad, T. F. 2013. Adding a cost of resistance description extends the 526 ability of virus-host model to explain observed patterns in structure and function of pelagic 527 microbial communities. Environ. Microbiol. 15: 18421852.

528 van Someren Gréve, H., Almeda, R., Kiørboe, T. 2017a. Motile behavior and predation risk in 529 planktonic copepods. Limnol. Oceanogr. 62: 1810-1824.

530 van Someren Gréve, H., Almeda, R., Lindegren, M., Kiørboe, T. 2017b. Gender-specific feeding 531 rates in planktonic copepods with different feeding behavior. J. Plankton Res. 39: 631-644.

532 Visser, A. W. 2007. Motility of zooplankton: fitness, foraging and predation. J. Plankton Res. 29: 533 447-461.

534 Vogt, R. A., Ignoffo, T. R., Sullivan, L. J., Herndon, J., Stillman, J. H., Kimmerer, W. J. 2013.

535 Feeding capabilities and limitations in the nauplii of two pelagic estuarine copepods,

536 Pseudodiaptomus marinus and Oithona davisae. Limnol. Oceanogr. 58: 2145-2157.

537 Winter, C., Bouvier, T., Weinbauer, M. G., Thingstad, T. F. 2010. Trade-Offs between competition 538 and defense specialists among unicellular planktonic organisms: the "killing the winner" hypothesis 539 revisited. Microbiol. Mol. Biol. Rev. 74: 42-57.

540 
548 Figure 1. Graphic abstract showing the main hypotheses of this study: i) ambush feeders are less 549 efficient than active feeders (feeding-current and cruising feeders) in acquiring resources, and (ii) 550 that ambushers are particularly poor in collecting non-motile prey. (a): feeding-current feeder, (b): 551 cruising feeder, (c): ambush feeder, 1: motile prey, 2: non-motile prey. We used planktonic copepod 552 nauplii and copepodites as model organisms.

Figure 2. Relationships between average food concentration during the incubation and clearance rates (empty circles; left axis) and ingestion rates (filled circles; right axis) of nauplii and copepodites of the ambush feeding copepod $O$. nana feeding on 4 different prey offered separately: R. salina (A-D), T. weissflogii (E-H), O. marina (I-L) and A. sanguinea (M-P). The discontinuous (for clearance rates) and continuous (for ingestion rates) curves correspond to the functional response models fitted to the data (equations 1-4). Details about experimental organisms, incubation conditions and model parameters are shown Table 1 and Table 2.

Figure 3. Relationships between average food concentration during the incubation and clearance discontinuous (for clearance rates) and continuous (for ingestion rates) curves correspond to the functional response models fitted to the data (equations 1-4). Details about experimental organisms, incubation conditions and model parameters are shown in Table 1 and Table 2. 
571 Figure 4. Relationship between average food concentration during the incubation and clearance rates (empty circles; left axis) and ingestion rates (filled circles; right axis) of nauplii and copepodites cruising feeder copepod C. hamatus feeding on 4 different prey offered separately: $R$. salina (A-C), T. weissflogii (D-G), the O. marina (H-K) and A. sanguinea (L-N). The discontinuous (for clearance rates) and continuous (for ingestion rates) curves correspond to the functional response models fitted to the data (equations 1-4). Details about experimental organisms, incubation conditions and model parameters are shown in Table 1 and Table 2.

\section{Figure 5. Top panels: Maximum clearance rates $(\beta)$ of nauplii and copepodites with different} feeding behaviors as a function of grazer body weight for different prey: the non- motile diatom $T$. weissflogii (A) and the motile prey the R salina (B), O. marina (C) and A. sanguinea (D). Linear regression equations fitted to the logarithmically transformed data are indicated in each panel (AD). Asterisk indicates an outlier (panel 5B). Bottom panels: Carbon-specific maximum clearance rates $\left(\beta_{s}, \mathrm{~mL} \mu \mathrm{g} \mathrm{C}^{-1} \mathrm{~d}^{-1}\right)$ of copepod developmental stages with different feeding behaviors (ambush feeding (E), cruising feeding (F), feeding-current feeding (G)) as function of prey to predator body carbon mass ratios. Coefficients \pm standard error of parameters $(\gamma, \mu, \sigma)$ of the Gauss function fitted to the data (eq. 5) are indicated in each panel (E-G). $r^{2}=$ coefficient of determination. 


\section{Table 1}

Summary of the functional response experiments with copepods with different feeding behaviors. Each experiment label (Exp \#) in the table corresponds to its label in the figures 2-4. N: nauplii, C: copepodite, $L$ : average body length for nauplii and prosome length for copepodites, $W$ : weight in carbon, SE: standard error, D: range of grazer concentration per experimental bottle, ESD: equivalent spherical diameter, SD: standard deviation, C: range of prey concentrations, R.s: Rhodomonas salina, T.w: Thalassiosira weissflogii, O.m: Oxyrrhis marina, A.s: Akashiwo sanguinea.

\begin{tabular}{|c|c|c|c|c|c|c|c|c|c|c|}
\hline \multicolumn{7}{|c|}{ Grazer } & \multicolumn{4}{|c|}{ Prey } \\
\hline Species & $\begin{array}{c}\text { Feeding } \\
\text { behavior }\end{array}$ & $\begin{array}{c}\text { Exp. } \\
\#\end{array}$ & Stage & $\begin{array}{c}L \pm \mathrm{SE} \\
(\mu \mathrm{m})\end{array}$ & $\begin{array}{c}W \pm \mathrm{SE} \\
\left(\mathrm{ng} \mathrm{C} \text { ind }^{-1}\right)\end{array}$ & $\begin{array}{c}\mathrm{D} \\
\text { (ind. bt }^{-1} \text { ) }\end{array}$ & Species & $\begin{array}{c}\mathrm{ESD} \pm \mathrm{SD} \\
(\mu \mathrm{m})\end{array}$ & $\begin{array}{c}W \pm \mathrm{SE} \\
\left(\mathrm{pg} \mathrm{C}^{\mathrm{cell}}{ }^{-1}\right)\end{array}$ & $\begin{array}{c}\mathrm{C} \\
\text { (cells } \mathrm{mL}^{-1} \text { ) }\end{array}$ \\
\hline \multirow{16}{*}{$\begin{array}{l}\text { Oithona } \\
\text { nana }\end{array}$} & \multirow{16}{*}{$\begin{array}{l}\text { Ambush } \\
\text { feeding }\end{array}$} & $1 \mathrm{~A}$ & $\mathrm{~N}$ & $82 \pm 1$ & $26 \pm 1$ & $67-310$ & $P s$ & \multirow{4}{*}{$8.6 \pm 1.1$} & \multirow{4}{*}{$28 \pm 0.1$} & \multirow{4}{*}{$567-21618$} \\
\hline & & 1B & $\mathrm{N}$ & $113 \pm 2$ & $53 \pm 2$ & $39-258$ & K. S & & & \\
\hline & & $1 \mathrm{C}$ & $\mathrm{N}$ & $127 \pm 3$ & $68 \pm 3$ & $31-206$ & & & & \\
\hline & & $1 \mathrm{D}$ & $\mathrm{C}$ & $183 \pm 4$ & $140 \pm 4$ & $20-85$ & & & & \\
\hline & & $1 \mathrm{E}$ & $\mathrm{N}$ & $95 \pm 2$ & $37 \pm 2$ & $115-300$ & & \multirow{4}{*}{$11.4 \pm 1.2$} & \multirow{4}{*}{$112 \pm 0.1$} & \multirow{4}{*}{ 48-1904 } \\
\hline & & $1 \mathrm{~F}$ & $\mathrm{~N}$ & $110 \pm 2$ & $50 \pm 2$ & $99-298$ & & & & \\
\hline & & $1 G$ & $\mathrm{~N}$ & $150 \pm 3$ & $96 \pm 3$ & $62-196$ & & & & \\
\hline & & $1 \mathrm{H}$ & $\mathrm{C}$ & $162 \pm 2$ & $115 \pm 2$ & $30-86$ & & & & \\
\hline & & $1 \mathrm{I}$ & $\mathrm{N}$ & $76 \pm 1$ & $23 \pm 1$ & $40-112$ & & \multirow{4}{*}{$13.3 \pm 1.2$} & \multirow{4}{*}{$152 \pm 0.1$} & \multirow{4}{*}{$17-994$} \\
\hline & & $1 \mathrm{~J}$ & $\mathrm{~N}$ & $89 \pm 2$ & $32 \pm 1$ & $32-104$ & & & & \\
\hline & & $1 \mathrm{~K}$ & $\mathrm{~N}$ & $131 \pm 3$ & $71 \pm 3$ & $21-80$ & & & & \\
\hline & & $1 \mathrm{~L}$ & $\mathrm{C}$ & $197 \pm 3$ & $157 \pm 5$ & $20-41$ & & & & \\
\hline & & $1 \mathrm{M}$ & $\mathrm{N}$ & $104 \pm 2$ & $44 \pm 2$ & $84-362$ & A. $s$ & \multirow{4}{*}{$39.4 \pm 1.1$} & \multirow{4}{*}{$1635 \pm 0.04$} & \multirow{4}{*}{$3-53$} \\
\hline & & $1 \mathrm{~N}$ & $\mathrm{~N}$ & $113 \pm 3$ & $53 \pm 3$ & $68-210$ & & & & \\
\hline & & 10 & $\mathrm{C}$ & $169 \pm 4$ & $123 \pm 5$ & $34-102$ & & & & \\
\hline & & $1 \mathrm{P}$ & $\mathrm{C}$ & $196 \pm 3$ & $157 \pm 4$ & $20-86$ & & & & \\
\hline \multirow{13}{*}{$\begin{array}{l}\text { Temora } \\
\text { longicornis }\end{array}$} & \multirow{13}{*}{$\begin{array}{l}\text { Feeding-current } \\
\text { feeding }\end{array}$} & $2 \mathrm{~A}$ & $\mathrm{~N}$ & $194 \pm 7$ & $112 \pm 10$ & $15-30$ & R. $s$ & \multirow{3}{*}{$7.2 \pm 1.1$} & \multirow{3}{*}{$17 \pm 0.1$} & \multirow{3}{*}{ 1916-16092 } \\
\hline & & $2 B$ & $\mathrm{~N}$ & $313 \pm 7$ & $304 \pm 13$ & $10-20$ & & & & \\
\hline & & $2 \mathrm{C}$ & $\mathrm{C}$ & $339 \pm 11$ & $497 \pm 52$ & $10-20$ & & & & \\
\hline & & $2 \mathrm{D}$ & $\mathrm{N}$ & $170 \pm 1$ & $80 \pm 1$ & $15-29$ & & & & \\
\hline & & $2 \mathrm{E}$ & $\mathrm{N}$ & $245 \pm 6$ & $181 \pm 9$ & $12-19$ & & $120+11$ & $130+01$ & $53-2660$ \\
\hline & & $2 \mathrm{~F}$ & $\mathrm{~N}$ & $308 \pm 7$ & $295 \pm 13$ & 8-12 & & $12.0 \pm 1.1$ & $130 \pm 0.1$ & $53-2000$ \\
\hline & & $2 \mathrm{G}$ & $\mathrm{C}$ & $321 \pm 5$ & $395 \pm 20$ & $6-10$ & & & & \\
\hline & & $2 \mathrm{H}$ & $\mathrm{N}$ & $201 \pm 6$ & $114 \pm 1$ & $14-30$ & $O . m$ & & & \\
\hline & & 2I & $\mathrm{N}$ & $281 \pm 5$ & $236 \pm 6$ & $10-25$ & & $14.3 \pm 1.2$ & $190 \pm 0.1$ & $10-468$ \\
\hline & & $2 \mathrm{~J}$ & $\mathrm{C}$ & $355 \pm 9$ & $551 \pm 40$ & $10-20$ & & & & \\
\hline & & $2 \mathrm{~K}$ & $\mathrm{~N}$ & $187 \pm 4$ & $98 \pm 5$ & $14-30$ & A. $s$ & & & \\
\hline & & $2 \mathrm{~L}$ & $\mathrm{~N}$ & $289 \pm 7$ & $256 \pm 12$ & $10-25$ & & $42.1 \pm 1.1$ & $1998 \pm 0.04$ & $3-54$ \\
\hline & & $2 \mathrm{M}$ & $\mathrm{C}$ & $323 \pm 5$ & $399 \pm 17$ & $10-18$ & & & & \\
\hline & & $3 \mathrm{~A}$ & $\mathrm{~N}$ & $142 \pm 1$ & $74 \pm 1$ & $41-67$ & R.s & & & \\
\hline & & 3B & $\mathrm{N}$ & $155 \pm 3$ & $92 \pm 4$ & $29-54$ & & $7.8 \pm 1.1$ & $21 \pm 0.1$ & 566-21380 \\
\hline & Cruising & $3 C$ & $\mathrm{~N}$ & $216 \pm 10$ & $202 \pm 20$ & $23-33$ & & & & \\
\hline & feeding & $3 \mathrm{D}$ & $\mathrm{N}$ & $132 \pm 3$ & $64 \pm 3$ & $26-49$ & & & & \\
\hline & & $3 \mathrm{E}$ & $\mathrm{N}$ & $170 \pm 5$ & $114 \pm 7$ & $20-46$ & & $117+12$ & $123+01$ & 42-1692 \\
\hline & & $3 F$ & $\mathrm{~N}$ & $248 \pm 7$ & $267 \pm 17$ & $15-34$ & & $11.7 \pm 1.2$ & & \\
\hline Centropages & & $3 G$ & $\mathrm{C}$ & $358 \pm 7$ & $581 \pm 30$ & $6-10$ & & & & \\
\hline hamatus & & $3 \mathrm{H}$ & $\mathrm{N}$ & $130 \pm 3$ & $62 \pm 3$ & $26-52$ & $\Omega$ & & & \\
\hline & & 3I & $\mathrm{N}$ & $179 \pm 5$ & $129 \pm 10$ & $22-41$ & & $126+12$ & $130+01$ & $18-870$ \\
\hline & & $3 \mathrm{~J}$ & $\mathrm{~N}$ & $196 \pm 5$ & $155 \pm 8$ & $18-29$ & & & & \\
\hline & & $3 \mathrm{~K}$ & $\mathrm{C}$ & $315 \pm 7$ & $426 \pm 26$ & $6-10$ & & & & \\
\hline & & 3L & $\mathrm{N}$ & $143 \pm 1$ & $75 \pm 2$ & $23-45$ & A.s & & & \\
\hline & & $3 \mathrm{M}$ & $\mathrm{N}$ & $173 \pm 3$ & $116 \pm 4$ & $17-28$ & 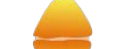 & $39.8 \pm 1.1$ & $1679 \pm 0.04$ & $3-52$ \\
\hline & & $3 N$ & $\mathrm{C}$ & $226 \pm 4$ & $350 \pm 13$ & $5-8$ & 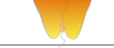 & & & \\
\hline
\end{tabular}


Table 2

Summary of the results from the functional feeding response experiments with copepods with different feeding behaviours. Each experiment label (Exp \#) in the table corresponds to its label in the figures 2-4. N: nauplii, C: copepodite, SE: standard error, R.s: Rhodomonas salina, T.w: Thalassiosira weissflogii, O.m: Oxyrrhis marina, A.s: Akashiwo sanguinea. $\beta$ is the maximum clearance rate ( $\left.\mathrm{mL}_{\text {ind }}{ }^{-1} \mathrm{~d}^{-1}\right), \tau$ is the prey handling time (d), $\alpha$ is the prey concentration at the maximum clearance rate, $r^{2}(F)=$ coefficient of determination for clearance rate model equations $(1,3) I_{\max }$ is the maximum ingestion rates (cells ind $\left.^{-1} \mathrm{~d}^{-1}\right)$, SE=standard error,; $\mathrm{r}^{2}(\mathrm{I})=$ coefficient of determination for ingestion rate model equations $(2,4)$., ${ }^{\mathrm{S}} \mathrm{I}_{\max }$ is the Cspecific maximum ingestion rates (=maximum daily ration, \% body $\mathrm{C}^{-1}$ ). The asterisk $\left(^{*}\right)$ indicates that the maximum measured rate was used instead of the model prediction if predictions were unrealistic or no model (II or II) could be fitted to the data.

\begin{tabular}{|c|c|c|c|c|c|c|c|c|c|c|c|}
\hline \multirow{2}{*}{$\begin{array}{l}\text { Feeding } \\
\text { behaviour }\end{array}$} & \multirow{2}{*}{$\begin{array}{l}\text { Exp. } \\
\#\end{array}$} & \multirow{2}{*}{ Stage } & \multirow{2}{*}{ Prey } & \multirow{2}{*}{$\begin{array}{l}\text { FR } \\
\text { type }\end{array}$} & \multicolumn{6}{|c|}{ Functional response model parameters } & \multirow[b]{2}{*}{${ }^{s} I_{\max } \pm \mathrm{SE}$} \\
\hline & & & & & $\beta \pm \mathrm{SE}$ & $\tau \pm \mathrm{SE}$ & $\alpha \pm \mathrm{SE}$ & $\mathrm{r}^{2}(\mathrm{~F})$ & $I_{\max } \pm \mathrm{SE}$ & $r^{2}(I)$ & \\
\hline \multirow{16}{*}{ Ambush feeding } & $1 \mathrm{~A}$ & $\mathrm{~N}$ & \multirow{4}{*}{ R. $s$} & III & $0.13 \pm 0.01$ & & $951 \pm 312$ & 0.76 & $264 \pm 95$ & 0.63 & $28 \pm 10$ \\
\hline & 1B & $\mathrm{N}$ & & III & $0.26 \pm 0.03$ & & $1485 \pm 217$ & 0.66 & $1132 \pm 264$ & 0.89 & $60 \pm 14$ \\
\hline & $1 \mathrm{C}$ & $\mathrm{N}$ & & III & $0.37 \pm 0.01$ & & $1083 \pm 101$ & 0.95 & $1178 \pm 324$ & 0.80 & $49 \pm 13$ \\
\hline & $1 \mathrm{D}$ & $\mathrm{C}$ & & III & $0.59 \pm 0.04$ & & $1250 \pm 171$ & 0.86 & $1512 \pm 276$ & 0.88 & $30 \pm 6$ \\
\hline & $1 \mathrm{E}$ & $\mathrm{N}$ & \multirow{5}{*}{ T. $w$} & II & $0.05 \pm 0.01$ & $0.007 \pm 0.011$ & & 0.37 & $149 \pm 245$ & 0.77 & $45 \pm 74$ \\
\hline & $1 \mathrm{~F}$ & $\mathrm{~N}$ & & II & $0.07 \pm 0.01$ & $0.014 \pm 0.011$ & & 0.64 & $74 \pm 59$ & 0.70 & $17 \pm 13$ \\
\hline & $1 \mathrm{G}$ & $\mathrm{N}$ & & II & $0.09 \pm 0.01$ & $0.016 \pm 0.015$ & & 0.54 & $79(*)$ & 0.87 & $9(*)$ \\
\hline & $1 \mathrm{H}$ & $\mathrm{C}$ & & III & $0.23 \pm 0.03$ & & $885 \pm 341$ & 0.63 & $210 \pm 96$ & 0.80 & $20 \pm 9$ \\
\hline & $1 \mathrm{I}$ & $\mathrm{N}$ & & III & $0.82 \pm 0.10$ & & $51 \pm 6$ & 0.65 & $140 \pm 28$ & 0.90 & $93 \pm 19$ \\
\hline & $1 \mathrm{~J}$ & $\mathrm{~N}$ & \multirow{2}{*}{ O. $m$} & III & $0.99 \pm 0.05$ & & $50 \pm 4$ & 0.83 & $180 \pm 27$ & 0.94 & $86 \pm 13$ \\
\hline & $1 \mathrm{~K}$ & $\mathrm{~N}$ & & III & $1.20 \pm 0.08$ & & $42 \pm 4$ & 0.68 & $225 \pm 57$ & 0.85 & $48 \pm 12$ \\
\hline & $1 \mathrm{~L}$ & $\mathrm{C}$ & \multirow{8}{*}{ R. $s$} & III & $2.41 \pm 0.24$ & & $27 \pm 5$ & 0.73 & $478 \pm 95$ & 0.86 & $46 \pm 9$ \\
\hline & $1 \mathrm{M}$ & $\mathrm{N}$ & & II & $0.10 \pm 0.01$ & $0.21 \pm 0.06$ & & 0.61 & $3.4 \pm 0.4$ & 0.96 & $13 \pm 1$ \\
\hline & $1 \mathrm{~N}$ & $\mathrm{~N}$ & & II & $0.27 \pm 0.05$ & $0.46 \pm 0.13$ & & 0.66 & $5.3 \pm 1.0$ & 0.92 & $16 \pm 3$ \\
\hline & 10 & $\mathrm{C}$ & & II & $1.47 \pm 0.17$ & $0.07 \pm 0.02$ & & 0.77 & $14 \pm 2$ & 0.83 & $19 \pm 3$ \\
\hline & $1 \mathrm{P}$ & $\mathrm{C}$ & & II & $1.48 \pm 0.18$ & $0.05 \pm 0.01$ & & 0.72 & $17 \pm 2$ & 0.79 & $18 \pm 2$ \\
\hline \multirow{13}{*}{$\begin{array}{l}\text { Feeding-current } \\
\text { feeding }\end{array}$} & $2 \mathrm{~A}$ & $\mathrm{~N}$ & & III & $0.44 \pm 0.02$ & & $3687 \pm 315$ & 0.50 & $4504 \pm 620$ & 0.94 & $68 \pm 9$ \\
\hline & $2 B$ & $\mathrm{~N}$ & & III & $0.84 \pm 0.05$ & & $4489 \pm 361$ & 0.58 & $9202 \pm 1257$ & 0.93 & $51 \pm 7$ \\
\hline & $2 \mathrm{C}$ & $\mathrm{C}$ & & III & $3.83 \pm 0.13$ & & $2338 \pm 168$ & 0.79 & $25234 \pm 2450$ & 0.95 & $86 \pm 8$ \\
\hline & $2 \mathrm{D}$ & $\mathrm{N}$ & \multirow{4}{*}{ T. $w$} & III & $1.02 \pm 0.15$ & & $109 \pm 21$ & 0.54 & $695 \pm 349$ & 0.75 & $113 \pm 57$ \\
\hline & $2 \mathrm{E}$ & $\mathrm{N}$ & & III & $5.10 \pm 0.50$ & & $85 \pm 9$ & 0.31 & $2753 \pm 654$ & 0.93 & $198 \pm 47$ \\
\hline & $2 \mathrm{~F}$ & $\mathrm{~N}$ & & III & $6.18 \pm 0.57$ & & $95 \pm 10$ & 0.42 & $3124 \pm 1142$ & 0.86 & $138 \pm 50$ \\
\hline & $2 \mathrm{G}$ & $\mathrm{C}$ & & III & $11.00 \pm 0.96$ & & $76 \pm 8$ & 0.25 & $6221 \pm 1321$ & 0.95 & $205 \pm 43$ \\
\hline & $2 \mathrm{H}$ & $\mathrm{N}$ & \multirow{3}{*}{ O. $m$} & II & $2.70 \pm 0.19$ & $0.003 \pm 0.001$ & & 0.76 & $588 \pm 35$ & 0.99 & $100 \pm 6$ \\
\hline & $2 \mathrm{I}$ & $\mathrm{N}$ & & II & $4.26 \pm 0.35$ & $0.003 \pm 0.001$ & & 0.77 & $588 \pm 69$ & 0.96 & $37 \pm 4$ \\
\hline & $2 \mathrm{~J}$ & $\mathrm{C}$ & & II & $6.72 \pm 0.36$ & $0.001 \pm 0.000$ & & 0.83 & $1250 \pm 156$ & 0.97 & $43 \pm 5$ \\
\hline & $2 \mathrm{~K}$ & $\mathrm{~N}$ & \multirow{3}{*}{ A. $s$} & III & $1.09 \pm 0.11$ & & $8.7 \pm 1.0$ & 0.40 & $27 \pm 3$ & 0.97 & $55 \pm 6$ \\
\hline & $2 \mathrm{~L}$ & $\mathrm{~N}$ & & III & $2.97 \pm 0.33$ & & $6.6 \pm 0.8$ & 0.51 & $46 \pm 8$ & 0.90 & $36 \pm 6$ \\
\hline & $2 \mathrm{M}$ & $\mathrm{C}$ & & III & $5.42 \pm 0.50$ & & $7.5 \pm 0.9$ & 0.66 & $87 \pm 15$ & 0.92 & $44 \pm 8$ \\
\hline \multirow{14}{*}{ Cruising feeding } & $3 \mathrm{~A}$ & $\mathrm{~N}$ & \multirow{3}{*}{ R. $s$} & III & $0.51 \pm 0.05$ & & $1050 \pm 70$ & 0.91 & $1256 \pm 198$ & 0.94 & $36 \pm 6$ \\
\hline & 3B & $\mathrm{N}$ & & III & $0.46 \pm 0.12$ & & $847 \pm 57$ & 0.91 & $2238 \pm 905$ & 0.80 & $51 \pm 21$ \\
\hline & $3 \mathrm{C}$ & $\mathrm{N}$ & & III & $0.59 \pm 0.10$ & & $1202 \pm 74$ & 0.85 & $3407 \pm 970$ & 0.90 & $35 \pm 10$ \\
\hline & $3 \mathrm{D}$ & $\mathrm{N}$ & \multirow{4}{*}{ T. $w$} & III & $1.59 \pm 0.15$ & & $122 \pm 13$ & 0.83 & $283 \pm 63$ & 0.89 & $54 \pm 12$ \\
\hline & $3 \mathrm{E}$ & $\mathrm{N}$ & & III & $1.97 \pm 0.22$ & & $101 \pm 14$ & 0.68 & $442 \pm 140$ & 0.82 & $48 \pm 15$ \\
\hline & $3 F$ & $\mathrm{~N}$ & & III & $5.73 \pm 0.42$ & & $43 \pm 4$ & 0.60 & $1354 \pm 185$ & 0.97 & $62 \pm 9$ \\
\hline & $3 G$ & $\mathrm{C}$ & & III & $12.5 \pm 1.15$ & & $50 \pm 5$ & 0.06 & $3430 \pm 379$ & 0.98 & $73 \pm 8$ \\
\hline & $3 \mathrm{H}$ & $\mathrm{N}$ & \multirow{4}{*}{ O. $m$} & III & $1.44 \pm 0.10$ & & $18 \pm 2$ & 0.61 & $412 \pm 42$ & 0.97 & $86 \pm 9$ \\
\hline & $3 \mathrm{I}$ & $\mathrm{N}$ & & III & $1.53 \pm 0.10$ & & $19 \pm 2$ & 0.47 & $481 \pm 66$ & 0.96 & $48 \pm 7$ \\
\hline & $3 \mathrm{~J}$ & $\mathrm{~N}$ & & III & $1.71 \pm 0.11$ & & $25 \pm 2$ & 0.20 & $573 \pm 59$ & 0.97 & $48 \pm 5$ \\
\hline & $3 \mathrm{~K}$ & $\mathrm{C}$ & & III & $5.16(*)$ & & $(*)$ & $(*)$ & $2203 \pm 197$ & 0.98 & $67 \pm 6$ \\
\hline & $3 \mathrm{~L}$ & $\mathrm{~N}$ & \multirow{3}{*}{ A.s } & III & $0.33 \pm 0.03$ & & $7.4 \pm 1.0$ & 0.51 & $6.8 \pm 1.8$ & 0.80 & $15 \pm 4$ \\
\hline & $3 \mathrm{M}$ & $\mathrm{N}$ & & III & $0.50 \pm 0.04$ & & $6.6 \pm 1.0$ & 0.62 & $7.3 \pm 2.0$ & 0.77 & $11 \pm 3$ \\
\hline & $3 N$ & $\mathrm{C}$ & & III & $5.69 \pm 0.20$ & & 3. $2 \pm 0.2$ & 0.92 & $61 \pm 9$ & 0.92 & $29 \pm 4$ \\
\hline
\end{tabular}




\section{Figure 1}
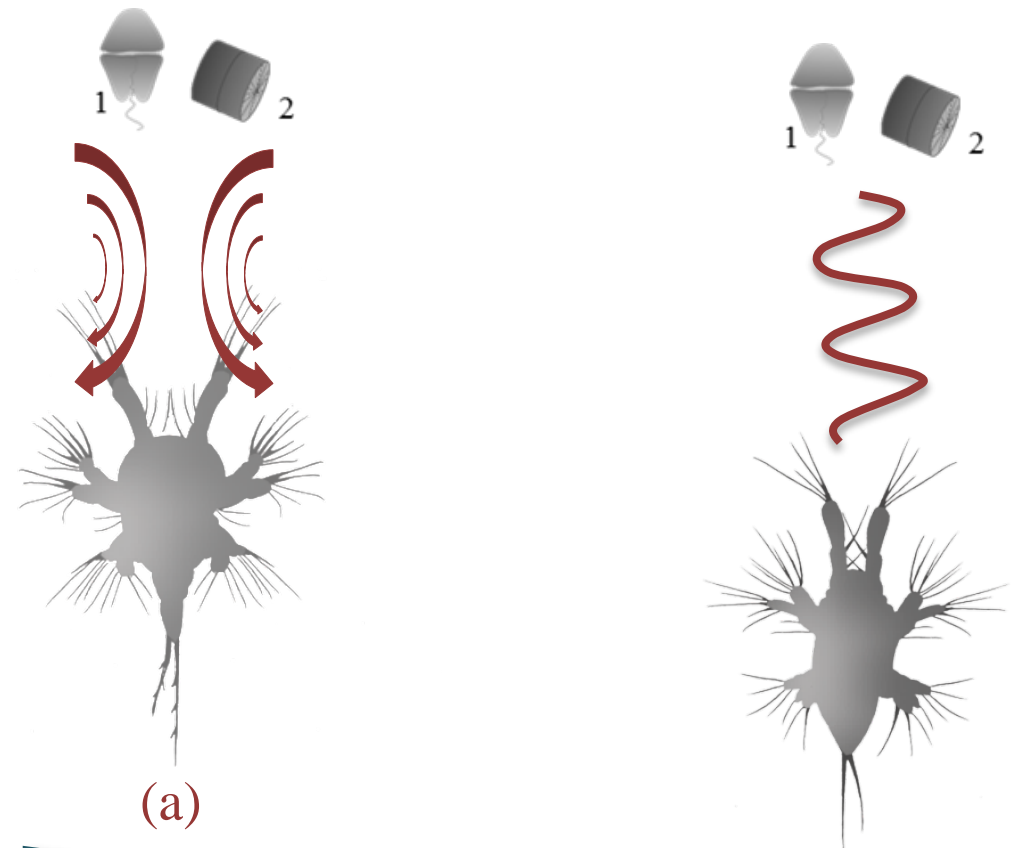

(b)

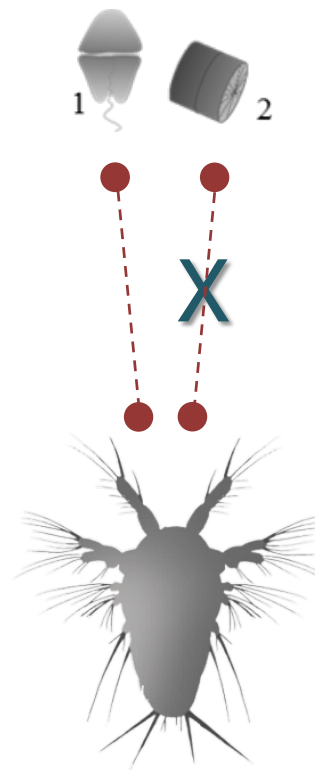

Maximum clearance rates

(c) 

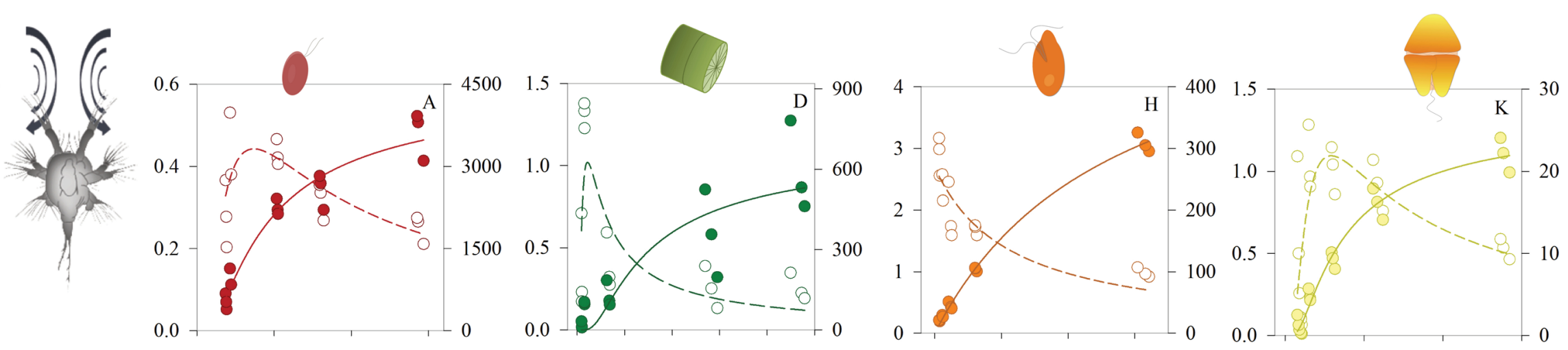

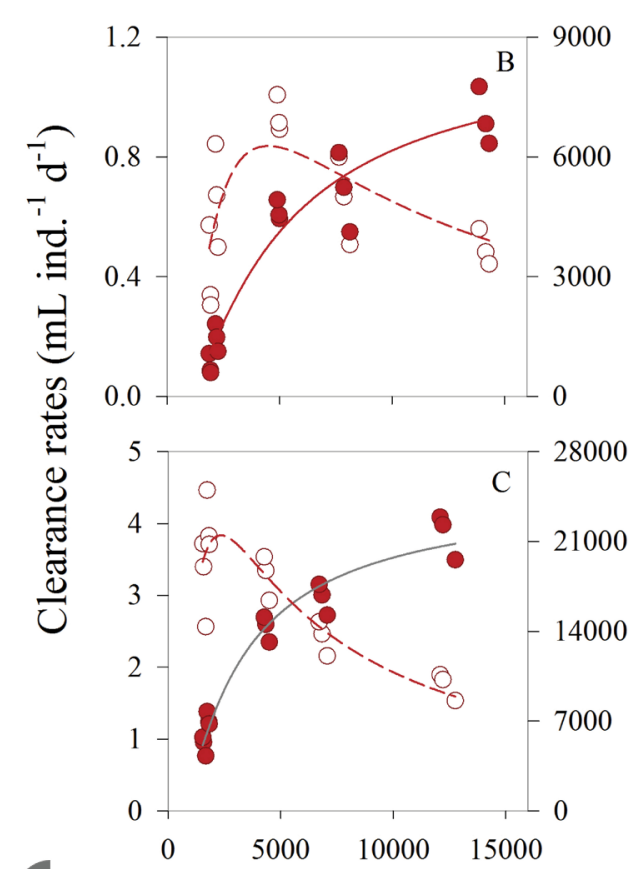

Rhodomonas salina conc. (cells $\mathrm{mL}^{-1}$ )
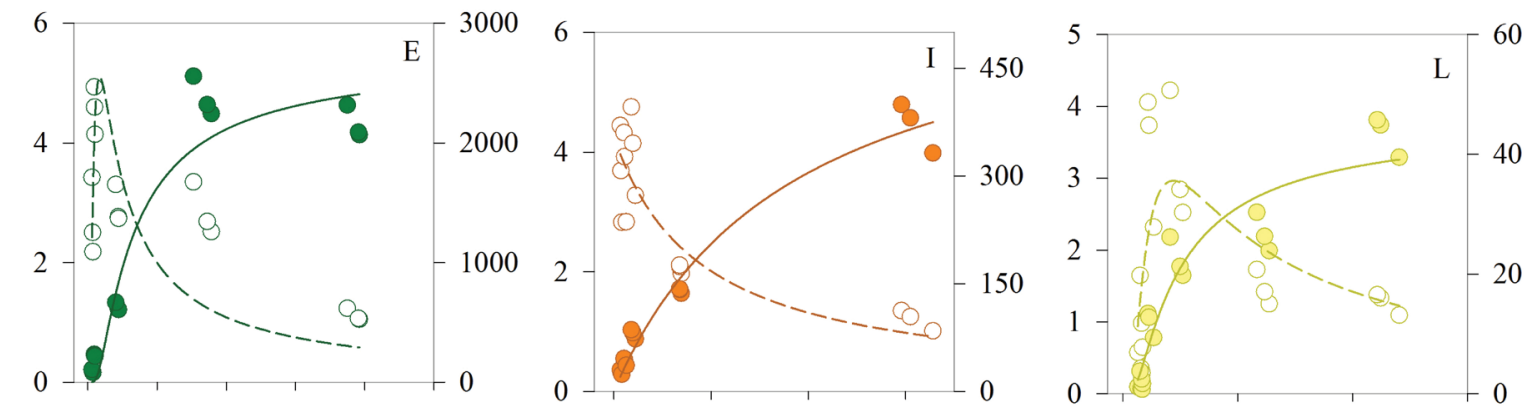
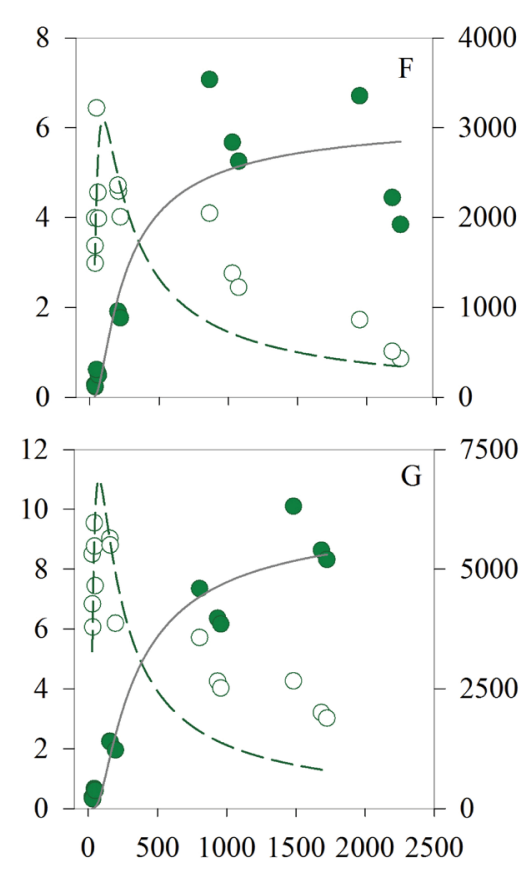

Thalassiosira weissflogii conc.

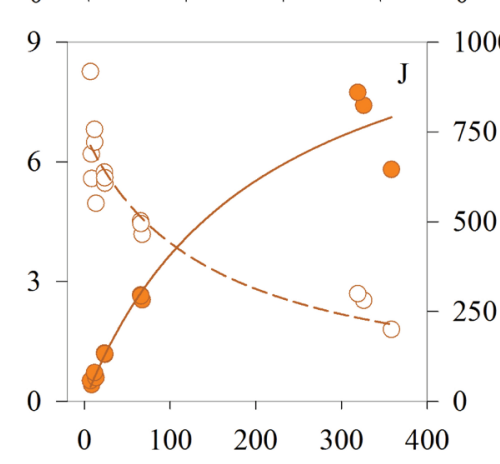

Oxyrrhis marina conc. (cells $\mathrm{mL}^{-1}$ )

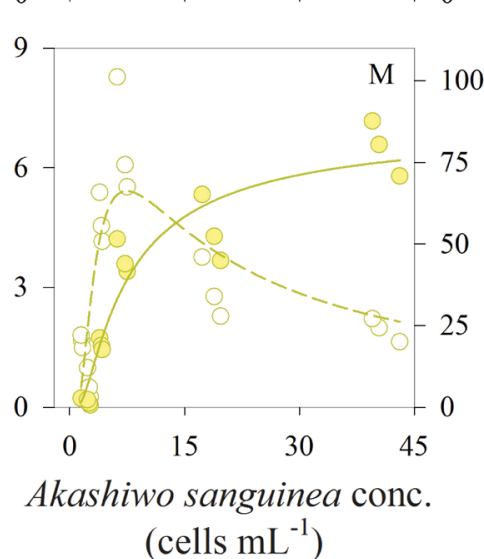

(cells $\mathrm{mL}^{-1}$ )

Figure 3

$$
\text { (cells } \mathrm{mL}^{-1} \text { ) }
$$



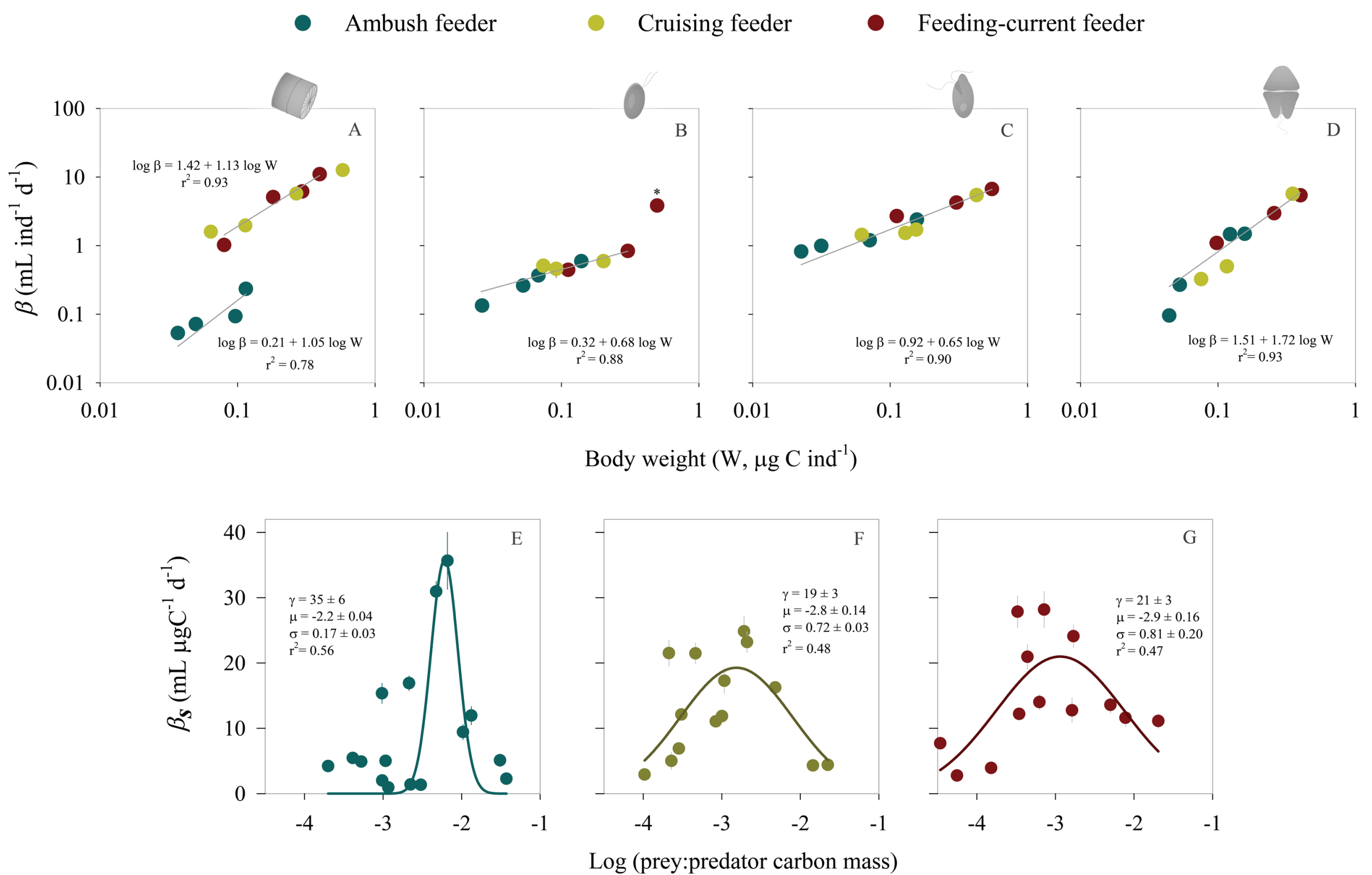

Figure 5 